\title{
OCCURRENCE OF SERRASSALMIDAE HYBRID FISH IN THE AMAZON RIVER BASIN, BRAZIL
}

\author{
Felipe Pontieri de Lima ${ }^{1^{*}}$, Andrea Abrigato de Freitas Mourão ${ }^{2}$, André Batista Nobile ${ }^{1}$, Diogo \\ Freitas-Souza $^{1}$, Fausto Foresti ${ }^{1}$, Claudio Oliveira ${ }^{1}$ \& Fábio Porto Foresti ${ }^{2}$
}

\begin{abstract}
${ }^{1}$ Universidade Estadual Paulista, Instituto de Biociências, Departamento de Morfologia, Laboratório de Biologia e Genética de Peixes, Rua Professor Doutor Antonio Celso Wagner Zanin, Campus Botucatu, CEP 18618-689, Botucatu, SP, Brazil.

${ }^{2}$ Universidade Estadual Paulista, Faculdade de Ciências de Bauru, Departamento de Ciências Biológicas, Laboratório de Genética de Peixes, Av. Engenheiro Luiz Edmundo Carrijo Coube, Núcleo Residencial Presidente Geisel, CEP 17033-360, Bauru, SP, Brazil.

E-mails: fpl.limao@hotmail.com (*corresponding author); aafmourao@yahoo.com.br; andrenobile@hotmail.com; souza.d.freitas@gmail.com, ffoiresti@ibb.unesp.br; claudio@ibb.unesp.br; fpforesti@fc.unesp.br
\end{abstract}

\begin{abstract}
This study reports a case of occurrence of hybrid fish in the Amazon River basin, Brazil and attentive on to possible risks promoted with from crossbreeding between two species on local biodiversity. The specimen was collected in February/2016, and was evaluated showing dubious characteristics indicating the possibility of the occurrence of hybridization. Thus, fin specimen fragments were sampled and the genetic analyzes were performed. Our results indicated that the studied sample had a heterozygous electrophoretic profile revealing itself as a hybrid between Piaractus brachypomus and Colossoma macropomum being the second species the maternal parent.
\end{abstract}

Keywords: genetic conservation; genetic markers; hybrid occurrence; crossbreeding; Neotropical ichthyofaunal.

\section{INTRODUCTION}

Interspecific hybridization can be defined as natural or human-induced crosses between different species. Interspecific hybridization occurs from six to ten percent of animal species in nature (Mallet 2005), being the phenomenon quite common in fishes, especially among freshwater species (Epifanio \& Nielsen 2000, Scribner et al. 2000). In this group factors such as external fertilization, competition for spawning habitat and disproportion in the sexual relation of the parental species are considered responsible agents for the greater occurrence of hybridization (Scribner et al. 2000).

Divergent views on the factors involved in hybridization make the topic widely discussed. According to Willis et al. (2012), hybridization is a natural phenomenon related to the speciation and diversification of individuals. So, when natural crossings occurs at random, during evolutionary history of species diversification, it may be considered as an important mechanism for the evolution of organisms, given the possibility of 
emergence of genotypic combinations that could establish new evolutionary lineages (Arnold \& Hodges 1995). On the other hand, hybridization events have also been treated as "genetic contamination" (Millar et al. 2012), since gene flow from innumerous interspecific crosses could lead to loss of genetic individuality of the species. Thus, the occurrence of hybridization in natural environment can both lead to the appearance of conditions conducive to the establishment of new gene clusters and individual adaptation, as well as the local extinction of populations and species (Dowling \& Secor 1997, Allendorf et al. 2001, Willis et al. 2012, Mirimin et al. 2014).

An aggravating factor in the fish species hybridization process is the practice of interspecific crosses in captivity, which over time has become a common and growing activity in the Brazilian aquaculture scenario (Brasil 2017). So, when it comes genetic contamination and the problems of hybridization, the process should be included as a possible threat to the species conservation, especially when resulting from human interferences, as the artificial production of hybrids in captivity or the escapees and releases of hybrid fishes in the wild. The activity is commercially interesting in fish farming because the hybrid individuals resulting from this process have peculiar biological characteristics and may even express better performance than the average of the parental lineages in several aspects (Bartley et al. 2000, Helfman et al. 2009). This improvement is known as heterosis or hybrid vigor and production aims to implement desirable characteristics to fish such as increased growth rate, decrease in nutritional requirements, disease resistance and better meat quality (Bartley et al. 2000, Hashimoto et al. 2011). In this sense, only until 2014, about 17 hybrid forms were already reported as being of common use for this purpose, being produced from 12 species of fish of the orders Characiformes and Siluriformes (Hashimoto et al. 2010, Alves et al. 2013, Moro et al. 2013).

Among the Serrassalmidae family, tambaqui (Colossoma macropomum (Cuvier, 1816)), pirapitinga (Piaractus brachypomus (Cuvier, 1818)), pacu (Piaractus mesopotamicus (Holmberg, 1887)) and their hybrids, are among the most cultivated fish in the national fish culture, highlighting the region north, northeast and center-west from
Brazil (IBAMA 2009). In view of the commercial representativeness of hybrids in fish farming and, on the other hand, the problems arising from the introduction of these individuals into the natural environment, diverse preventive measures of great importance should be taken with the purpose of avoiding escapes from fish farms (Azevedo-Santos et al. 2015).

According to Hashimoto et al. (2010), the monitoring of hybrids in the natural environment or even in crop stocks is not simple, because the occurrence of hybridization events, especially with regard to secondary and advanced effects, such as the occurrence of introgression and backcrossing with local populations, may result in individuals morphologically similar to the parental (Allendorf et al. 2001, Porto-Foresti et al. 2013), hindering the morphological differentiation.

The use of molecular markers that help in the identification of parental lines and products resulting from hybridization are valuable tools, once they make it possible to detect and study these biological events, both in the culture conditions and in wild (Scribner et al. 2000, Mourão et al. 2017). The present study aims to report the occurrence of a hybrid individual found in natural environment in the Apiacás River, a component of the Teles Pires River basin, which currently suffers different types of anthropic pressure as a consequence of local development. It is considered that the results reported here are of ecological importance since, despite the increasing impact and changes registered, the region still presents characteristics favorable to the implementation of conservation measures.

For the present study, a specimen initially identified as $P$. brachypomus ("pirapitinga"), voucher LBP 21582, belonging to the collection of the Laboratório de Biologia e Genética de Peixes (UNESP, Botucatu, São Paulo) was used. The specimen was collected in February/2016 in the Apiacás River (10²1'00.7” S, 5658'56.7” W), municipality of Alta Floresta, state of Mato Grosso, part of the upper Teles Pires basin, drainage of the Tapajós River (Figure 1).

Morphological analyses of this fish, based on the identification key proposed by Queiroz et al. (2013), showed dubious characteristics, especially the absence of rays in the adipose fin, indicating the possibility of the occurrence of hybridization. 


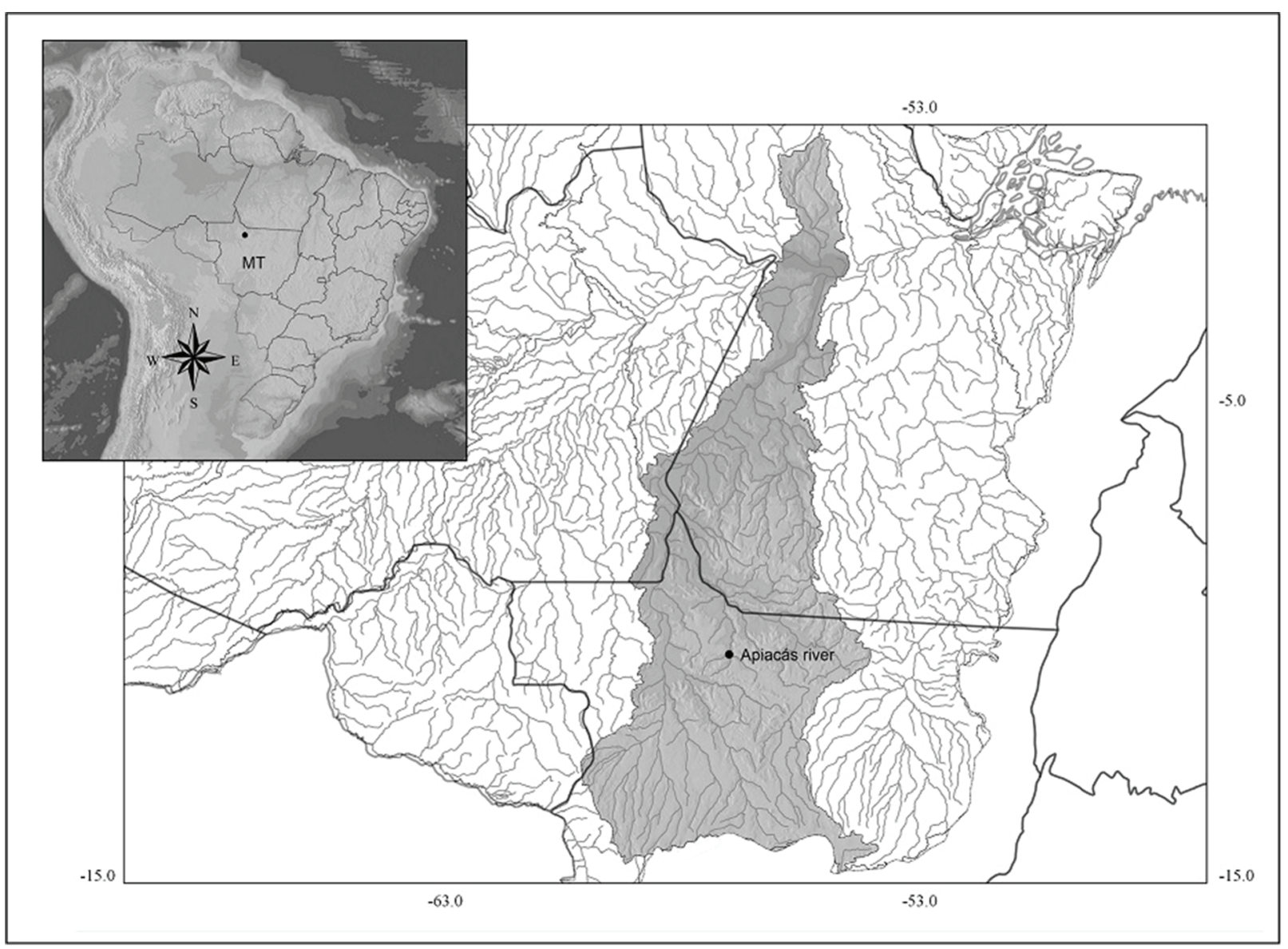

Figure 1. Map indicating the occurrence location of the fish sample collected in the natural environment in the Apiacás River (10²1'0.74”S 56 58'56.70”O). Grey region highlights the Tapajos River basin in the central part of South America. MT = state of Mato Grosso, Brazil. Note: scale: 1 degree $111.12 \mathrm{Km}$

Thus, fin specimen fragments were sampled and stored in the tissue bank of the Laboratório de Genética de Peixes (UNESP, Bauru, São Paulo), where the genetic analyzes were performed. For a better evaluation of the possible hybridization event, tissue samples from three species of Serrasalmidae (Figure 2) (Piaractus mesopotamicus (Holmberg, 1887), P. brachypomus and Colossoma macropomum), where used as controls, and were obtained from the Centro Nacional de Pesquisa e Conservação de Peixes Continentais/Instituto Chico Mendes da Conservação de Biodiversidade, municipality of Pirassununga, state of São Paulo.

DNA extraction was performed based on the protocol of the commercial kit "Wizard Genomic DNA Purification Kit - Promega" and their quantification was done through the equipment Qubit 3.0 Fluorometer. Genetic identification of the individuals was performed thought a PCRMultiplex technique using multiple primers for the markers of type PCR (Polymerase Chain Reaction)Multiplex technique using multiple primers for the markers $\alpha$-tropomyosin genes (TROP - nuclear) and cytochrome C oxidase subunit I (COI mitochondrial) (Table 1). The methodology was performed using the primers listed in Table I and under the conditions described by Hashimoto et al. (2011).

Amplifications by PCR-Multiplex (Polymerase Chain Reaction- Multiplex) were performed in a total volume of $25 \mu \mathrm{l}$ with $200 \mu \mathrm{M}$ of each dNTP (dATP, dTTP, dGTP and dCTP), $1.5 \mathrm{mM}$ of $\mathrm{MgCl} 2$, $1 \times$ Taq DNA buffer (20 mM Tris-HCl, pH 8.4 and $50 \mathrm{mM} \mathrm{KCl}$ ), 0.5 units of Taq DNA Polymerase (Invitrogen), $0.1 \mu \mathrm{M}$ of each primer and 10-50ng of DNA. All reactions were performed in thermocycler (Mastercycler personal, Eppendorf) under conditions of 5 minutes of denaturation at $95^{\circ} \mathrm{C}, 35$ cycles for: TROP $\left(95^{\circ} \mathrm{C}\right.$ for $30 \mathrm{sec}, 60^{\circ} \mathrm{C}$ for $30 \mathrm{sec}$ and $72^{\circ} \mathrm{C}$ for $\left.10 \mathrm{sec}\right) ; \mathrm{COI}\left(95^{\circ} \mathrm{C}\right.$ for $30 \mathrm{sec}, 50^{\circ} \mathrm{C}$ for $30 \mathrm{sec}$ and $72^{\circ} \mathrm{C}$ for $45 \mathrm{sec}$ ) and $7 \mathrm{~min}$ of final extension at $72^{\circ} \mathrm{C}$.

The genetic identification of the species was based on the observation of the species-specific 


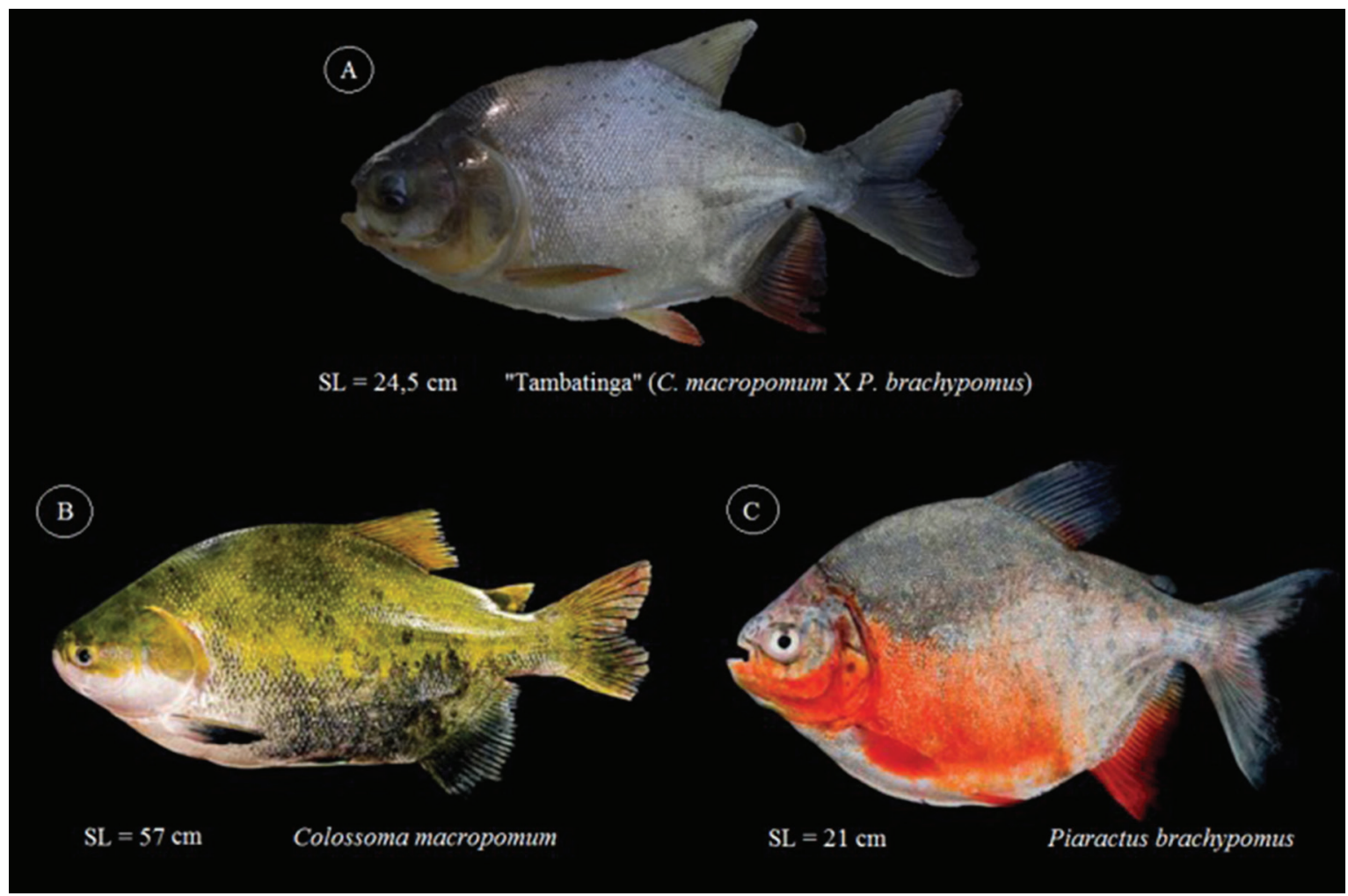

Figure 2. Images of the individual and analyzed species: A) "Tambatinga" hybrid (C. macropomum X P. Brachypomuns); B) Colossoma macropomum; and C) Piaractus brachypomuns. Note: Images B and C obtained from Queiroz et al. (2013) with the permission of the authors..

electrophoretic profile for each of the molecular markers, visualized on $1.5 \%$ agarose gel stained with Nancy (Sigma) $(0.0225 \mu \mathrm{l} / \mathrm{ml})$ and photographed in transluminator (Loccus Biotechnology) under ultraviolet light.

Genetic analyzes of the TROP (nuclear) revealed diagnostic bands of $270 \mathrm{bp}$ for P. mesopotanicus ("pacu"), $130 \mathrm{bp}$ for P. brachypomus ("pirapitinga") and $170 \mathrm{bp}$ for C. macropomum ("tambaqui"). The study sample presented a heterozygous electrophoretic profile, with bands of $130 \mathrm{bp}$ and $170 \mathrm{bp}$, corresponding to an interspecific hybrid between $P$. brachypomus and $C$. macropomum (Figure 3A).

Genetic analysis of the COI (mitochondrial) revealed diagnostic bands in the $300 \mathrm{bp}$ and $610 \mathrm{pb}$ samples for P. mesopotamicus ("pacu") and P. brachypomus ("pirapitinga") and $430 \mathrm{bp}$ for C. macropomum ("tambaqui"). The study sample presented a band of $430 \mathrm{bp}$, revealing $C$. macropomum ("tambaqui") as its maternal parent (Figure 3B).

Two determining factors were considered decisive in this particular study: 1) the dubious

Table 1. Sequences of the primers and polymerase chain reaction (PCR) conditions used to amplify given gene fragments.

\begin{tabular}{|c|c|c|}
\hline Primers & 5' --- Sequence of primers --- 3' & Reference \\
\hline TROP Cm R & ATACAACAATGCCATCGCT & Hashimoto et al. 2011 \\
\hline TROP Pb R & TTGACTTTATGCCACACAAAT & Hashimoto et al. 2011 \\
\hline TROP Pm R & CTTCAGCTGGATCTCCTGA & Hashimoto et al. 2011 \\
\hline TROP Serra F & GAGTTGGATCGGGCTCAG & Hashimoto et al. 2011 \\
\hline COI Cm R & AGCAAGATGGAGTGAGAAAATA & Hashimoto et al. 2011 \\
\hline COI Pb R & CTGTCAGAAGTATAGTAATTCCG & Hashimoto et al. 2011 \\
\hline COI Piaractus R & GAAGGAAGGATGGGGGTAGG & Hashimoto et al. 2011 \\
\hline
\end{tabular}




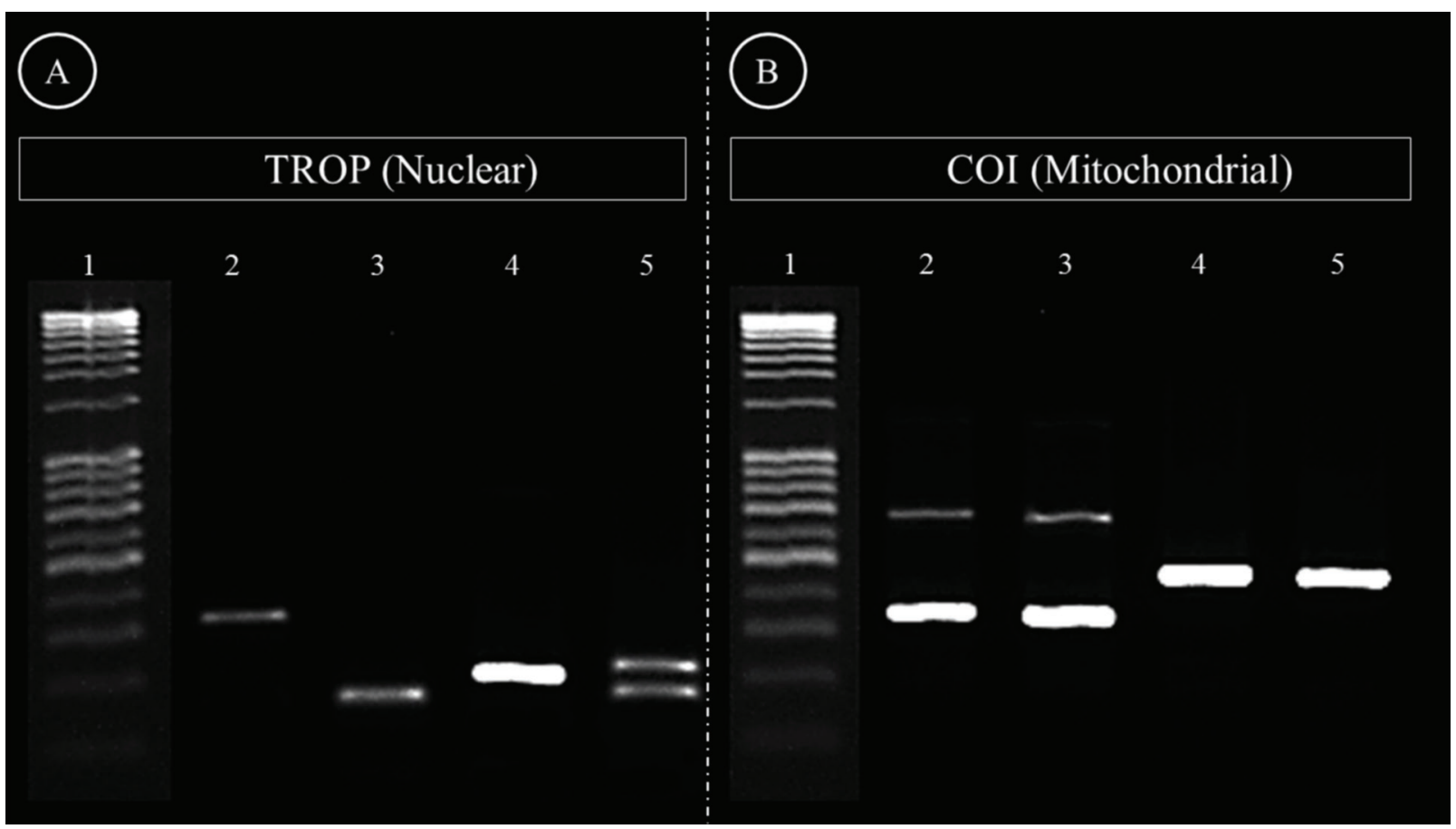

Figure 3. Electrophoresis analysis of multiplex-PCR using species-specific primers for the nuclear TROP (A) and mitochondrial COI (B). 1) Ladder; 2) Piaractus mesopotamicus; 3) Piaractus brachypomus; 4) Colossoma macropomum; and 5) possible hybrid sample "Tambatinga".

morphology between $P$. brachypomuns and $C$. macropomum presented by the studied specimen, based on the identification of the specific key (Queiroz et al. 2013); and 2) the presence of important fish farming companies located in this region of the State of Mato Grosso (Brasil 2017). This region, are currently considered the third largest fish producer in the country, including the production of hybrid forms of round fish such as "tambatinga (Brasil 2017). In this way, genetic analyzes with molecular markers of nuclear and mitochondrial origin were performed to evaluate the morphological differences presented by the studied specimen.

The hybrid "Tambatinga" has great commercial importance, since it represents one of the main sources of production of the national aquaculture (IBAMA 2009). It is also worth noting that, according to IBAMA (2009), the production of this hybrid has even exceeded that of its parent species $P$. brachypomus. However, even with their production and commercial representativeness, there are still few studies evaluating the effects of their presence in natural environments, as well as the effects on wild populations of parental lineages (Hashimoto et al. 2012).

In general, the technology needed to promote hybridization among species of Serrasalmidae is considered well established and widely used in fish farming systems (Hashimoto et al. 2014). Thus, the fish culture of this group varies among different regions of Brazil and is considered to be simpler and feasible than the production of other hybrids and pure species (Hashimoto et al. 2014). However, there are still few studies on the performance, genetic and ecological impacts that hybridization and hybrid products may have on the environment (Hashimoto et al. 2010).

In this sense, in addition to reporting the occurrence of this hybrid in nature, this work aims to highlight possible risks promoted by individuals from crossbreeding between two species on local biodiversity. According to Silva et al. (2009), reproductive aspects are highlighted since the occurrence of a sterile hybrid in a natural environment, although it does not have a reproductive capacity, can compete for food resources, territorial resources or even breeding sites. In the latter case, according to the same authors, a great loss could occur in relation to the recruitment of the species, since the eggs of an active native female could have contact with infeasible semen of a sterile hybrid male, affecting the reproductive performance of the species. In the case of the hybrid product being fertile, the genetic impact on the native species could also act to reduce 
population size, since the genes of the hybrid products would be incorporated into the genome of the natural species promoting introgression processes (Silva et al. 2009). In this case, depending on adaptive ability and reproductive capacity, the hybrid could increase its distribution area along the basin and raise its population density, jeopardizing the viability of pure species (Silva et al. 2009).

Hashimoto et al. (2010) reported that viability studies were performed only in hybrids of $P$. mesopotamicus x C. macropomum and Pseudoplatystoma corruscans x Pseudoplatystoma reticulatum. In this sense, Ribeiro et al. (1995) and Toledo-Filho et al. (1998) found that although these animals are profitable in aquaculture because they present a hybrid vigor, they can also be fertile and able of reproducing with their parental species, and its occurrence in the environment is considered an imminent threat to the wild communities.

In this work, we highlight that although some authors consider that hybridization can occur naturally (Epifanio \& Nielsen 2000, Scribner et al. 2000), the various anthropic actions, with consequent "genetic contamination" of the wild stocks of ichthyofauna, have been promoting an imbalance and acceleration in these occurrences. This contamination may be due to the morphological similarity between non-native individuals, hybrid and pure strains, which causes mixtures in the formation of seedlings in fish farms (Toledo-Filho et al. 1994), a fact corroborated by Hashimoto et al. (2014), who observed erroneous labeling when analyzing more than 900 individuals from Brazilian fish farms.

In addition to the morphological similarity between the groups, the situation may be aggravated, since native and hybrid individuals may present similar ecological relations, presenting related reproductive behaviors. This can lead to unsuccessful crosses with parental species, resulting in unviable descendants, or presenting agonistic behavior as territorial dispute, interfering in the reproductive dynamics of pure species (Toledo-Filho et al. 1994). Moreover, they may promote backcrossing or genetic introgression in the original ichthyofauna, an observation corroborated by Prado et al. (2017) and Sales et al. (2018).

In this way, considering the threats of presence of hybrids may offers to the natural environment and our record of one hybrid in the Apiacás River, considered as an environment still preserved and wild, the problem of leaks or releases in natural environments can become even more dangerous to the ecological balance, as already evidenced in systems of culture in tank network (Azevedo-Santos et al.2011)including Brazil. This form of production, although economically productive, may cause several impacts to the environment. Considering the historical relationship between aquaculture and species introduction, our study investigated the potential of cage aquaculture in spreading non-native species into hydroelectric reservoirs. We interviewed 19 fish farmers in Furnas Reservoir, Grande River basin. All producers have grown exclusively Nile tilapia (Oreochromis niloticus. Once the expansion and growth of this type of activity traces increasingly sharp perspectives of high production and increased possibility of leaks. So, the premise of stablishing well-defined rules for the management of species in the environment should also be considered as a preventive way of create conditions for the conservation of native species (Moyle \& Light 1996, Vermeij 1996).

Despite the strong evidence that the introduction is from anthropogenic actions, the possibility that the individual being studied is not a product of escape from fish farming should be considered, since the eventual cross-species occurrence is relatively common among fish in natural conditions (Utsunomia et al. 2014, Cruz et al. 2015).

The results of the present study warn of the increasing production of fish hybrids and suggest that the practice be monitored and supervised by responsible environmental agencies, since several reports of escape have been recorded (Hashimoto et al. 2010, Prado et al. 2011, Gomes et al. 2012, Prado et al. 2012, Vaini et al. 2014, Yabu et al. 2018). It also stresses that molecular identification tools that can aid in research and conservation programs are of great importance and applicability and should be routinely used. It is considered that such information may assist in the monitoring the environment and of stocks, preserving the conditions and maintenance of wild stocks of fish species. 


\section{ACKNOWLEDGMENTS}

We would like to thanks Thiago S. Pires and Bruno S. Barros for granting images of specimens Colossoma macropomum and Piaractus brachypomuns obtained from the book "Peixes do Rio Madeira".

\section{REFERENCES}

Allendorf, F. W., Leary, R. F., Spruell, P., \& Wenburg, J. K. 2001. The problems with hybrids: setting conservation guidelines. Trends in Ecology \& Evolution, 16(11), 613-622. DOI: 10.1016/S01695347(01)02290-X

Alves, A., Varela, E., \& Hashimoto, D. 2013. Genética aplicada a piscicultura. In: A. P. O. Rodrigues, A. Lima, A. Alves, D. Rosa, L. Torati, \& V. SANTOS, V. (Orgs.), Piscicultura de água doce: multiplicando conhecimentos. p. 273-300. Brasília, DF: EMBRAPA.

Arnold, M. L., \& Hodges, S. A. 1995. Are natural hybrids fit or unfit relative to their parents? Trends in Ecology \& Evolution, 10(2), 67-71. DOI: 10.1016/S0169-5347(00)88979-X

Azevedo-Santos, V. M., Rigolin-Sá, O., \& Pelicice, F. M. 2011. Growing, losing or introducing? Cage aquaculture as a vector for the introduction of non-native fish in Furnas Reservoir, Minas Gerais, Brazil. Neotropical Ichthyology, 9(4), 915919. DOI: 10.1590/S1679-62252011000400024

Azevedo-Santos, V. M., Pelicice, F. M., LimaJunior, D. P., Magalhães, A. L. B., Orsi, M. L., Vitule, J. R. S., \& Agostinho, A. A. 2015. How to avoid fish introductions in Brazil: education and information as alternatives. Natureza \& Conservação, 13(2), 123-132 DOI: 10.1016/j. ncon.2015.06.002.

Bartley, D. M., Rana, K., \& Immink, A. J. 2000. The use of inter-specific hybrids in aquaculture and fisheries. Reviews in Fish Biology and Fisheries, 10(3), 325-337. DOI: 10.1023/A:1016691725361

Brasil. 2017. Produção de peixes no Brasil cresce com apoio de pesquisas da Embrapa. Retrieved from http://www.brasil.gov.br/economia-eemprego/2017/01/producao-de-peixes-nobrasil-cresce-com-apoio-de-pesquisas-daembrapa

Cruz, V. P., Vera, M., Mendonça, F. F., Pardo, B. G.,
Martinez, P., Oliveira, C., \& Foresti, F. 2015. First identification of interspecies hybridization in the freshwater stingrays Potamotrygon motoroand $P$. falkneri (Myliobatiformes, Potamotrygonidae). Conservation Genetics, 16(1), 241-245. DOI: 10.1007/s10592-014-0642-8

Dowling, T. E., \& Secor, C. L. 1997. The role of hybridization and introgression in the diversification of animals. Annual Review of Ecology and Systematics, 28(1), 593-619. DOI: 10.1146/annurev.ecolsys.28.1.593

Epifanio, J., \& Nielsen, J. 2000. The role of hybridization in the distribution, conservation and management of aquatic species. Reviews in Fish Biology and Fisheries, 10(3), 245-251. DOI: 10.1023/A:1016729132297

Gomes, F., Schneider, H., Barros, C., Sampaio, D., Hashimoto, D., Porto-Foresti, F., \& Sampaio, I. 2012. Innovative molecular approach to the identification of Colossoma macropomum and its hybrids. Anais da Academia Brasileira de Ciências, 84(2), 517-526. DOI: 10.1590/S000137652012005000025

Hashimoto, D. T., Mendonça, F. F., Senhorini, J. A., Bortolozzi, J., Oliveira, C., Foresti, F., \& PortoForesti, F. 2010. Identification of hybrids between Neotropical fish Leporinus macrocephalus and Leporinus elongatus by PCR-RFLP and multiplex-PCR: Tools for genetic monitoring in aquaculture. Aquaculture, 298(3-4), 346-349. DOI: 10.1016/j.aquaculture.2009.11.015

Hashimoto, D. T., Mendonça, F. F., Senhorini, J. A., Oliveira, C., Foresti, F., \& Porto-Foresti, F. 2011. Molecular diagnostic methods for identifying Serrasalmid fish (Pacu, Pirapitinga, and Tambaqui) and their hybrids in the Brazilian aquaculture industry. Aquaculture, 321(1-2), 49-53. DOI: 10.1016/j.aquaculture.2011.08.018

Hashimoto, D. T., Senhorini, J. A., Foresti, F, Martínez, P., \& Porto-Foresti, F. 2014. Genetic identification of F1 and post-F1 Serrasalmid juvenile hybrids in Brazilian aquaculture. PLoS ONE, 9(3), e89902. DOI: 10.1371/journal. pone.0089902

Hashimoto, D. T., Senhorini, J. A., Foresti, F., \& Porto-Foresti, F. 2012. Interspecific fish hybrids in Brazil: management of genetic resources for sustainable use. Reviews in Aquaculture, 4(2), 108-118. DOI: 10.1111/j.1753-5131.2012.01067.x Helfman, G., Collette, B. B., Facey, D. E., \& Bowen, 
B. W. 2009. The diversity of fishes: biology, evolution, and ecology. Oxford: Wiley-Blackwell: p. 736.

IBAMA. 2009. Estatística da pesca 2007: Brasil grandes regiões e unidades da Federação. In: E. Calaf, \& T. Maria José (Orgs.), Estatística da pesca 2007: Brasil - grandes regiões e unidades da Federação. Brasília, DF: IBAMA: p. 113.

Mallet, J. 2005. Hybridization as an invasion of the genome. Trends in Ecology \& Evolution, 20(5), 229-237. DOI: 10.1016/j.tree.2005.02.010

Millar, M. A., Byrne, M., Nuberg, I. K., \& Sedgley, M. 2012. High levels of genetic contamination in remnant populations of Acacia saligna from a genetically divergent planted stand. Restoration Ecology, 20(2), 260-267. DOI: 10.1111/j.1526100X.2010.00758.X

Mirimin, L., Kerwath, S. E., Macey, B. M., Bestervan der Merwe, A. E., Lamberth, S. J., Bloomer, P., \& Roodt-Wilding, R. 2014. Identification of naturally occurring hybrids between two overexploited sciaenid species along the South African coast. Molecular Phylogenetics and Evolution, 76, 30-33. DOI: 10.1016/j. ympev.2014.02.010

Moro, G. V., Rezende, F. P., Alves, A. L., Hashimoto, D. T., Varela, E. S., \& Torati, L. S. 2013. Espécies de peixe para piscicultura. In: A. P. O. Rodrigues, A. F. Lima, A. L. Alves, D. K. Rosa, L. S. Torati, \& V. R. V Santos (Orgs.), Piscicultura de água doce: multiplicando conhecimentos. p. 29-70. Brasília, DF: EMBRAPA.

Mourão, A. A. F., Freitas-Souza, D., Hashimoto, D. T., Ferreira, D. C., Prado, F. D., Silveira, R. V., Foresti, F., \& Porto-Foresti, F. 2017. Molecular and morphological approaches for species delimitation and hybridization investigations of two Cichla species. Iheringia, Série Zoologia, 107(e2017016), 1-9. DOI: 10.1590/1678$4766 \mathrm{e} 2017016$

Moyle, P. B., \& Light, T. 1996. Biological invasions of fresh water: Empirical rules and assembly theory. Biological Conservation, 78(1-2), 149161. DOI: 10.1016/0006-3207(96)00024-9

Prado, F. D., Fernandez-Cebrián, R., Hashimoto, D. T., Senhorini, J. A., Foresti, F., Martínez, P., \& Porto-Foresti, F. 2017. Hybridization and genetic introgression patterns between two South American catfish along their sympatric distribution range. Hydrobiologia, 788, 319-343.
DOI: $10.1007 / \mathrm{s} 10750-016-3010-5$

Prado, F. D., Hashimoto, D. T., Mendonça, F. F., Senhorini, J.A., Foresti, F., \& Porto-Foresti, F. 2011. Molecular identification of hybrids between Neotropical catfish species Pseudoplatystoma corruscans and Pseudoplatystoma reticulatum. Aquaculture Research, 42(12), 1890-1894. DOI: 10.1111/j.1365-2109.2010.02777.x

Prado, F. D., Hashimoto, D. T., Senhorini, J. A., Foresti, F., \& Porto-Foresti, F. 2012. Detection of hybrids and genetic introgression in wild stocks of two catfish species (Siluriformes: Pimelodidae): The impact of hatcheries in Brazil. Fisheries Research, 125-126, 300-305. DOI: 10.1016/j.fishres.2012.02.030

Porto-Foresti, F., Hashimoto, D. T., Senhorini, J. A., \& Foresti, F. 2013. Hibridação em piscicultura: monitoramento e perspectivas. In: B. Bernardo, \& L. de C. Gomes (Orgs.), Espécies nativas para piscicultura no Brasil. p. 589-606. 2 Santa Maria: Editora da Univerdidade Federal de Santa Maria. Queiroz, L. J., Vilara, G. T., Ohara, W. M., Pires, T. H. S., Zuanon, J., \& Doria, C. R. C. 2013. Peixes do Rio Madeira. São Paulo: Dialeto Latin American Documentary: p. 351.

Ribeiro, C. R., Santos, H. S. L., \& Bolzan., A. A. 1995. Estudo comparativo da embriogenese de peixes osseos (Pacu, Piaractus mesopotamicus; tambaqui, Colossoma macropomum e hibrido tambacu). Revista Brasileira de Biologia, 55, 65-78.

Sales, N. G., Pessali, T. C., Andrade Neto, F. R., \& Carvalho, D. C. 2018. Introgression from nonnative species unveils a hidden threat to the migratory Neotropical fish Prochilodus hartii. Biological Invasions, 20(3), 555-566. DOI: 10.1007/s10530-017-1556-4

Scribner, K. T., Page, K. S., \& Bartron, M. L. 2000. Hybridization in freshwater fishes: a review of case studies and cytonuclear methods of biological inference. Reviews in Fish Biology and Fisheries, 10(3), 293-323. DOI: 10.1023/A:1016642723238

Silva, S. S. De, Nguyen, T. T. T., Turchini, G. M., Amarasinghe, U. S., \& Abery, N. W. 2009. Alien species in aquaculture and biodiversity: A paradox in food production. AMBIO: A Journal of the Human Environment, 38(1), 24-28. DOI: 10.1579/0044-7447-38.1.24

Toledo-Filho, S. A., Almeida-Toledo, L. F., Foresti, 
F., Bernardino, G., \& Calcagnotto, D. 1994. Monitoramento e conservação genética em projeto de hibridação entre pacu e tambaqui. CCS/USP. Cadernos de Ictiogenética, 2, 1-25.

Toledo-Filho, S. A., Almeida-Toledo, L. F., Foresti, F, Calcagnotto, D., Santos, S. B. A. F., \& Bernardino, G. 1998. Programas genéticos de seleção, hibridação e endocruzamento aplicados à piscicultura. São Paulo: Cadernos de Ictiogenética 4, CCS/USP: p. 56.

Utsunomia, R., Pansonato Alves, J. C., Paiva, L. R. S., Costa Silva, G. J., Oliveira, C., Bertollo, L. A. C., \& Foresti, F. 2014. Genetic differentiation among distinct karyomorphs of the wolf fish Hoplias malabaricus species complex (Characiformes, Erythrinidae) and report of unusual hybridization with natural triploidy. Journal of Fish Biology, 85(5), 1682-1692. DOI: $10.1111 /$ jfb. 12526

Vaini, J. O., Grisolia, A. B., Prado, F. D., \& PortoForesti, F. 2014. Genetic identification of interspecific hybrid of Neotropical catfish species (Pseudoplatystoma corruscans vs. Pseudoplatystoma reticulatum) in rivers of Mato Grosso do Sul State, Brazil. Neotropical Ichthyology, 12(3), 635-641. DOI: 10.1590/19820224-20130169

Vermeij, G. J. 1996. An agenda for invasion biology. Biological Conservation, 78(1-2), 3-9. DOI: 10.1016/0006-3207(96)00013-4

Willis, S. C., Macrander, J., Farias, I. P., \& Ortí, G. 2012. Simultaneous delimitation of species and quantification of interspecific hybridization in Amazonian peacock cichlids (genus Cichla) using multi-locus data. BMC Evolutionary Biology, 12(1), 96. DOI: 10.1186/1471-2148-1296

Yabu, M. H. S., Vidotto-Magnoni, A. P., Casimiro, A. C. R., Garcia, D. A.Z., Costa, A. D. A., Prado, F. D.D., Porto-Foresti, F., \& Orsi, M. L. 2018. First record of non-native hybrid catfish Pseudoplatystoma reticulatum $\mathrm{x}$ Leiarius marmoratus in the Upper Paraná River basin, Brazil. Journal of Fish Biology, 92(1), 261-267. DOI: 10.1111/jfb.13505 